\title{
Can the Application of Municipal Sewage Sludge Compost in the Aided Phytostabilization Technique Provide an Effective Waste Management Method?
}

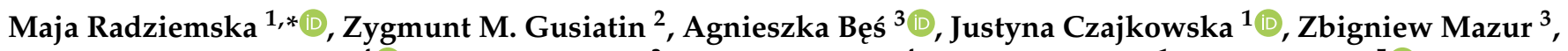 \\ Tereza Hammerschmiedt ${ }^{4}{ }^{\mathbb{D}}$, Łukasz Sikorski ${ }^{3}$, Eliska Kobzova ${ }^{4}$, Barbara K. Klik ${ }^{1}$, Wojciech Sas ${ }^{5}{ }^{\circledR}$, \\ Ernesta Liniauskiene ${ }^{6}$, Jiri Holatko ${ }^{4}$ and Martin Brtnicky ${ }^{4,7}$ (])
}

Citation: Radziemska, M.; Gusiatin, Z.M.; Bęś, A.; Czajkowska, J.; Mazur, Z.; Hammerschmiedt, T.; Sikorski, Ł.; Kobzova, E.; Klik, B.K.; Sas, W.; et al. Can the Application of Municipal Sewage Sludge Compost in the Aided Phytostabilization Technique Provide an Effective Waste Management Method? Energies 2021, 14, 1984. https://doi.org/10.3390/en14071984

Academic Editors: Attilio Converti and Agnieszka Cydzik-Kwiatkowska

Received: 9 March 2021

Accepted: 30 March 2021

Published: 2 April 2021

Publisher's Note: MDPI stays neutral with regard to jurisdictional claims in published maps and institutional affiliations.

Copyright: (c) 2021 by the authors Licensee MDPI, Basel, Switzerland. This article is an open access article distributed under the terms and conditions of the Creative Commons Attribution (CC BY) license (https:// creativecommons.org/licenses/by/ $4.0 /)$.
1 Institute of Environmental Engineering, Warsaw University of Life Sciences, Nowoursynowska 159, 02-776 Warsaw, Poland; justyna_czajkowska@sggw.edu.pl (J.C.); barbara_klik@sggw.edu.pl (B.K.K.)

2 Department of Environmental Biotechnology, Faculty of Geoengineering, University of Warmia and Mazury in Olsztyn, Słoneczna St. 45G, 10-719 Olsztyn, Poland; mariusz.gusiatin@uwm.edu.pl

3 Faculty of Environmental Management and Agriculture, University of Warmia and Mazury in Olsztyn, Pl. Łódzki 4, 10-727 Olsztyn, Poland; agnieszka.bes@uwm.edu.pl (A.B.); zbigniew.mazur@uwm.edu.pl (Z.M.); lukasz.sikorski@uwm.edu.pl (Ł.S.)

4 Department of Agrochemistry, Soil Science, Microbiology and Plant Nutrition, Faculty of AgriSciences, Mendel University in Brno, 61300 Brno, Czech Republic; tereza.hammerschmiedt@mendelu.cz (T.H.); eliska.kobzova@mendelu.cz (E.K.); jiri.holatko@mendelu.cz (J.H.); martin.brtnicky@seznam.cz (M.B.)

5 SGGW Water Centre, Warsaw University of Life Sciences-SGGW, 02-787 Warsaw, Poland; wojciech_sas@sggw.edu.pl

6 Hydrotechnical Construction Department, Kaunas University of Applied Sciences, Liepu Str. 1, LT-53101 Girionys, Kaunas District, Lithuania; e.liniauskiene@kmaik.lm.lt

7 Institute of Chemistry and Technology of Environmental Protection, Faculty of Chemistry, Brno University of Technology, 61200 Brno, Czech Republic

* Correspondence: maja_radziemska@sggw.edu.pl; Tel.: +48-2259-353-70

Abstract: (1) Background: sewage sludge is a by-product of wastewater treatment, which needs to be managed appropriately, e.g., in composting processes. The application of municipal sewage sludge composts (MSSCs) as a soil amendment is a potential way to effectively manage sewage sludge. (2) Methods: this paper presents the results of a vegetation pot experiment undertaken to assess the suitability of Dactylis glomerata L. and MSSC in the aided phytostabilization technique when applied on soils from an area effected by industrial pressure; this is characterized by high levels of heavy metal (HM). The contents of HMs in the test plant (the roots and above-ground parts), as well as in the soil and MSSC, were determined via an atomic spectrometry method. (3) Results: the application of MSSC positively contributed to an increased production of plant biomass and an increase in the $\mathrm{pH}$ in the soil. Concentrations of $\mathrm{Cu}, \mathrm{Cd}, \mathrm{Pb}, \mathrm{Zn}$, and $\mathrm{Cr}$ were higher in the roots than in the above-ground parts of Dactylis glomerata L. The addition of MSSC contributed most significantly to the considerable reduction in $\mathrm{Ni}, \mathrm{Pb}$, and $\mathrm{Zn}$ contents in the soil after the experiment. (4) Conclusions: MSSC can support the phytostabilization of soils contaminated with high levels of HMs.

Keywords: organic amendments; bioremediation; risk minimization

\section{Introduction}

A wide range of organic wastes may be used, either directly or following appropriate treatment, in the biological and/or chemical reclamation of degraded areas [1]. For this purpose, municipal sewage sludge (MSS), which is predominantly sourced from wastewater treatment plants, can be used [2,3]. Another aspect is directly related to MSS itself, whose ever-increasing volume requires safe management methods to be developed [4]. Since 2010, there has been a systematic increase in the amount of sewage sludge generated in Poland, and based on demographic assumptions, this trend is forecast to continue. In 
$2019,1,048,700$ tons of dry matter sewage sludge was produced, which was $0.2 \%$ more than in 2018 [5]. The final management of MSS often causes many problems, and it should be stressed that the physico-chemical and biological composition of MSS determines the selection of its management method [6]. With regards to MSS, the most frequent reference is to its recovery, i.e., the conversion into energy or valuable products according to the circular economy strategy. To this end, several measures are necessary to bring MSS to a condition that does not endanger people and/or the environment [7]. MSS can be successfully used as a compost mixture component. Composting is a microbiological process of converting organic waste, which takes place under aerobic conditions, and results in partial mineralization and humification of organic matter [8].

Soils contaminated with heavy metals (HMs) require effective reclamation methods to be applied. Relevant measures may include the introduction of organic matter in these areas, such as municipal sewage sludge compost (MSSC). Such treatments can significantly speed up soil reclamation while increasing soil productivity [9]. MSS converted into composts can be used to support processes taking place during aided phytostabilization of soils which are contaminated with heavy metals. Phytostabilization is an effective, noninvasive, cost-effective, aesthetically pleasing, and environmentally friendly alternative to physical remediation methods that interfere with the ecosystem [10]. This technique involves the immobilization of heavy metals, which takes place due to the absorption and accumulation of metals in plant roots, adsorption on the surface of the roots, or precipitation in the rhizospheric zone [11]. The role of plants with regard to the occurrence of heavy metals in soils results from their direct effect on the soil environment and the chemistry of contamination [12]. Organic compounds produced by plants and released into the rhizosphere, as well as $\mathrm{CO}_{2}$, can alter the $\mathrm{pH}$ of the soil, affect its oxidoreductive potential and reduce heavy metal ions into forms unavailable to plants [13]. Immobilized HMs have a reduced ability to move deeper into the soil profile and further into groundwater, and thus move into the further links of the food chain [14].

It should be noted that degraded areas are those with unfavorable conditions for vegetation development [15]. Therefore, it seems reasonable to introduce various types of soil amendments to effectively support the formation of dense and stable vegetation cover. Of all the organic soil amendments used to date in the aided phytostabilization technique, the following can be mentioned: various types of compost, peat, as well as lignite-based organic and mineral fertilizers (biocarbons) $[10,16,17]$. Therefore, the aim was to determine the effect of an organic soil amendment, i.e., MSSC, on supporting the process of phytostabilization of soils severely contaminated with HMs. Although composts were tested as soil amendments, MSSC was proposed here first time for aided phytostabilization of soil from a steel disposal dump. We hypothesized that MSSC has a positive effect on the immobilization of HMs. The experiments were conducted using Dactylis glomerata L., which is known as a good phytostabilizer of metals in contaminated soil [18]. The effectiveness of phytostabilization was assessed based on the test plant biomass yield, the accumulation of HMs in above-ground parts of the test plant, the roots and the contents of HMs in the soil.

\section{Materials and Methods}

\subsection{Soil Characterization}

The pot experiment used soil severely contaminated with HMs sourced from an area in north-eastern Poland, where a variety of metal and steel waste, as well as used batteries, had been stored for 75 years. The sampled and chemically degraded soil was characterized by a low moisture content and an alkaline $\mathrm{pH}(8.4 \pm 0.13)$. Based on particle size analysis, the soil was classified as loamy sand ( $72.2 \%$ sand, $26.4 \%$ silt, and $1.4 \%$ clay). Moreover, it was poor in nutrients and exhibited relatively high cation exchange capacity $(56.8 \pm 0.11 \mathrm{cmol} / \mathrm{kg})$ as well as a low organic matter content $(1.08 \pm 0.09 \%)$. Conversely, it contained large amounts of heavy metals such as $\mathrm{Cd}, \mathrm{Cu}, \mathrm{Cr}, \mathrm{Ni}, \mathrm{Pb}$, and $\mathrm{Zn}$ (as seen in Table 1). 
Table 1. The contents of heavy metals (HMs) in the soil from degraded areas, used in the experiment ( $\mathrm{n}=3$, mean \pm standard deviation).

\begin{tabular}{ccc}
\hline Metal & Unit & Concentration \\
\hline $\mathrm{Cd}$ & $\mathrm{mg} / \mathrm{kg}$ & $25.9 \pm 2.4$ \\
$\mathrm{Cu}$ & $\mathrm{mg} / \mathrm{kg}$ & $780.3 \pm 127.7$ \\
$\mathrm{Cr}$ & $\mathrm{mg} / \mathrm{kg}$ & $534.9 \pm 59.2$ \\
$\mathrm{Ni}$ & $\mathrm{mg} / \mathrm{kg}$ & $119.3 \pm 23.2$ \\
$\mathrm{~Pb}$ & $\mathrm{mg} / \mathrm{kg}$ & $13,540 \pm 669.6$ \\
$\mathrm{Zn}$ & $\mathrm{mg} / \mathrm{kg}$ & $8433 \pm 1376.5$ \\
\hline
\end{tabular}

The soils were sampled from the surface layer $(0-25 \mathrm{~cm})$ using a stainless-steel shovel. At each sampling point, a pooled soil sample of approximately $50 \mathrm{~kg}$ was prepared via a thorough mixing of four subsamples. The collected soil samples were transferred into clean and properly labelled polyethylene bags and then transported to the laboratory. Samples were then air-dried at room temperature and passed through a $2 \mathrm{~mm}$ sieve. Before setting up the pot experiment, the soil was stored in a refrigerator at a temperature of $4{ }^{\circ} \mathrm{C}$.

\subsection{MSSC as Soil Amendment}

The pot experiment used compost produced from MSS $(60 \% w / w)$ mixed with wooden chips $(15 \% w / w)$, rape straw $(22 \% w / w)$ and mature compost as inoculation $(3 \% w / w)$ [19]. The MSS was characterized by a humidity of $83 \%$, volatile organic matter of $71 \%$ and $\mathrm{C} / \mathrm{N}$ ratio of 5.1. The concentrations of $\mathrm{Cd}, \mathrm{Cu}, \mathrm{Cr}, \mathrm{Ni}, \mathrm{Pb}$, and $\mathrm{Zn}$ (in $\mathrm{mg} / \mathrm{kg} \mathrm{d.m}$.) were 1.1, 42.1, $60.1,21.2,14.3,299.3$, respectively. The lignocellulosic materials (i.e., wooden chips and rape straw) were characterized by a high level of volatile organic matter $(92 \%$, on average) and a high $\mathrm{C} / \mathrm{N}$ ratio (40, on average). Waste porosity, humidity and C:N ratio were important for their proper composting. This is because the MSS was characterized by a low porosity, high humidity and low C:N ratio, and its mixing with lignocellulosic materials (e.g., wood chips and rape straw) was necessary to improve the above characteristics. The compost was produced in laboratory scale bioreactor, and matured for 12 months in a turned windrow [19]. The physical and chemical characteristics of the compost used in the experiment are presented in Table 2.

Table 2. Selected physical and chemical characteristics of municipal sewage sludge compost (MSSC) ( $\mathrm{n}=3$, mean \pm standard deviation).

\begin{tabular}{ccc}
\hline Characteristic & Unit & Value \\
\hline Brunauer-Emmet-Teller specific surface area & $\mathrm{m}^{2} / \mathrm{g}$ & 12.5 \\
Total area in pores & $\mathrm{m}^{2} / \mathrm{g}$ & 1.13 \\
Total volume in pores & $\mathrm{cm}^{3} / \mathrm{g}$ & 0.011 \\
$\mathrm{pH}$ & - & $7.1 \pm 0.2$ \\
Electrical conductivity & $\mathrm{mS} / \mathrm{cm}$ & $12.2 \pm 0.4$ \\
Volatile organic matter ${ }^{\mathrm{a}}$ & $\%$ & $34.7 \pm 0.7$ \\
Cation exchange capacity & $\mathrm{cmol} / \mathrm{kg}$ & $49.5 \pm 1.4$ \\
$\mathrm{Cd}$ & $\mathrm{mg} / \mathrm{kg}$ & $0.8 \pm 0.2$ \\
$\mathrm{Cr}$ & $\mathrm{mg} / \mathrm{kg}$ & $55.2 \pm 2.8$ \\
$\mathrm{Cu}$ & $\mathrm{mg} / \mathrm{kg}$ & $57.6 \pm 7.6$ \\
$\mathrm{Ni}$ & $\mathrm{mg} / \mathrm{kg}$ & $23.4 \pm 3.6$ \\
$\mathrm{~Pb}$ & $\mathrm{mg} / \mathrm{kg}$ & $8.2 \pm 0.8$ \\
$\mathrm{Zn}$ & $\mathrm{mg} / \mathrm{kg}$ & $253.7 \pm 18.2$ \\
\hline${ }^{\mathrm{a}}$ determined by ignition of the samples at $550^{\circ} \mathrm{C}$.
\end{tabular}

\subsection{Pot Experiment}

The pot experiment was conducted across five replications in a greenhouse under natural day/night conditions; during the day $(14 \mathrm{~h})$, the air temperature was $26 \pm 3{ }^{\circ} \mathrm{C}$ and $\sim 10^{\circ}$ lower $\left(16 \pm 2{ }^{\circ} \mathrm{C}\right)$ at night $(10 \mathrm{~h})$, with a relative humidity of $75 \pm 5 \%$ for 
approximately 61 days. The soil with MSSC had a dose of 3.0\% $(w / w)$ after being previously mixed, and the soils without compost $(0.0 \%, w / w)$ were designated as the control, and placed in pots with a capacity of $5.0 \mathrm{~kg}$. The pots were then placed in a dark room for over two weeks to equilibrate the soil mixture. Following this, seeds of Dactylis glomerata L. cv. Berta were sown at $5 \mathrm{~g}$ per pot. The plants were watered every other day with distilled water, and filled to $60 \%$ of the maximum water holding capacity (field capacity) of the soil by adding deionized water. After the experiment was completed, soil samples, aboveground parts and the roots of the test plant were collected from each pot.

\subsection{Plant and Soil Analyses}

The above-ground parts and roots of Dactylis glomerata L. were initially washed in tap water, then, in deionized water and dried at room temperature. Prior to the analyses, the plants were ground in an analytical mill (Retsch type ZM300, Hann, Germany). The material obtained in this way was mineralized in nitric acid $\left(\mathrm{HNO}_{3}\right.$ p.a. grade) and $30 \%$ $\mathrm{H}_{2} \mathrm{O}_{2}$ using a microwave oven MARSXpress (CEM Corporation, Matthews, NC, USA). After filtration, the mineralized samples were made up to a volume of $100 \mathrm{~mL}$ with ultrapure water (Milli-Q System, USA). The obtained extracts were analyzed for their total levels of $\mathrm{Cd}, \mathrm{Cu}, \mathrm{Cr}, \mathrm{Ni}, \mathrm{Pb}$ and $\mathrm{Zn}$ by the flame atomic absorption spectrometry (FAAS, Varian, AA28OFS, Mulgrave, Australia). Prior to analyses, the soils were dried at room temperature for two weeks. In the soil samples, the $\mathrm{pH}$ and $\mathrm{EC}$ values were determined in distilled water extracts (1:2.5 w/v) using a pH-meter (Model HI 221, Orion, USA) and a conductometer (Model HI 8733, Orion, USA). The soil particle sizes were determined using a Mastersizer 2000 Analyser (Malvern, UK). The cation exchange capacity (CEC) of the soil and MSSC was calculated as the sum of hydrolytic acidity (in $\left.1 \mathrm{M} \mathrm{Ca}\left(\mathrm{CH}_{3} \mathrm{COO}\right)_{2}\right)$ and exchangeable bases (in $0.1 \mathrm{M} \mathrm{HCl}$ ) [20]. In order to determine the total contents of $\mathrm{HMs}$ in the soil and MSSC, the samples were mineralized in a mixture of concentrated $\mathrm{HCl}, \mathrm{HNO}_{3}$ and $\mathrm{H}_{2} \mathrm{O}_{2}$ in a microwave oven (MARSXpress, CEM Corporation, Matthews, $\mathrm{NC}$, USA). The contents of $\mathrm{Cd}, \mathrm{Cu}, \mathrm{Cr}, \mathrm{Ni}, \mathrm{Pb}$ and $\mathrm{Zn}$ were determined using the FAAS method. The quality of these analyses was assessed using reference material (CRM 142 $\mathrm{R}$ ) and the obtained recoveries (ratio of measured metal concentration to certified metal concentration), which ranged from $95 \%$ to $101 \%$. All analyses of the soil, compost and plants were conducted in triplicate.

\subsection{Statistical Analysis}

The statistical analysis of obtained results was conducted using Statistica 13.3 software. The data were analyzed using a one-way analysis of variance (ANOVA) or, where the ANOVA assumptions were not satisfied, the Kruskal-Wallis test by ranks as the statistical method. For the data with significant differences identified between variables, further analyses were conducted following the application of Tukey's test (HSD).

\section{Results and Discussion}

\subsection{The Effect of MSSC Application on the Yield of Dactylis glomerata L.}

Soils contaminated with HMs are generally characterized by a low nutrient availability to plants, a low organic matter content, weight of microorganisms, and poor vegetation cover as compared to non-contaminated soils [21,22]. Based on the results compiled in Figure 1, it can be concluded that the effect of MSSC addition on the yield of Dactylis glomerata L., tested in the experiment, differentiated it significantly $(p<0.05)$. The decrease in plant yield in the control series pots could be explained by the elevated HM contents in the soil [23]. Many authors point out that a rapid decrease in biomass can be observed when high HM levels are present in the soil [24,25], and the degree of plant tolerance to excessive amounts of HMs is primarily determined by the $\mathrm{pH}$, granulometric composition, organic matter content and plant species [26,27]. The application of organic waste materials such as MSSC has a positive effect on the utilization of the components they contain, which may result in an increase in plant biomass [28,29]. This is particularly 
important in degraded areas where the rapid restoration of an adequately dense vegetation cover is crucial [30]. In the conducted study, the application of MSSC resulted in an increase in the test plant yield by $63 \%$ in relation to the control series. The literature data indicate a positive effect the application of composts had on increasing in the yield of Lolium pereene $\mathrm{L}$. and Lupinus luteus L. during the experiment on aided phytostabilization of soils contaminated with $\mathrm{Ni}, \mathrm{Cd}, \mathrm{Cu}, \mathrm{Zn}$, and $\mathrm{Pb}$ [4,31]. A study by Zhang et al. [32] on the fertilization of Calathea insignis L., presented in the literature, proves the positive response of this species to the compost fertilization applied. Moreover, since compost contains considerable amounts of macronutrients, mostly in bioavailable forms, the nutrients provided by the compost are more strongly bound in the sorption complex [33]. Thus, their losses due to leaching are minimized, which consequently leads to the conclusion that the application of composts as soil amendments may ensure the high quality of yields obtained [34].

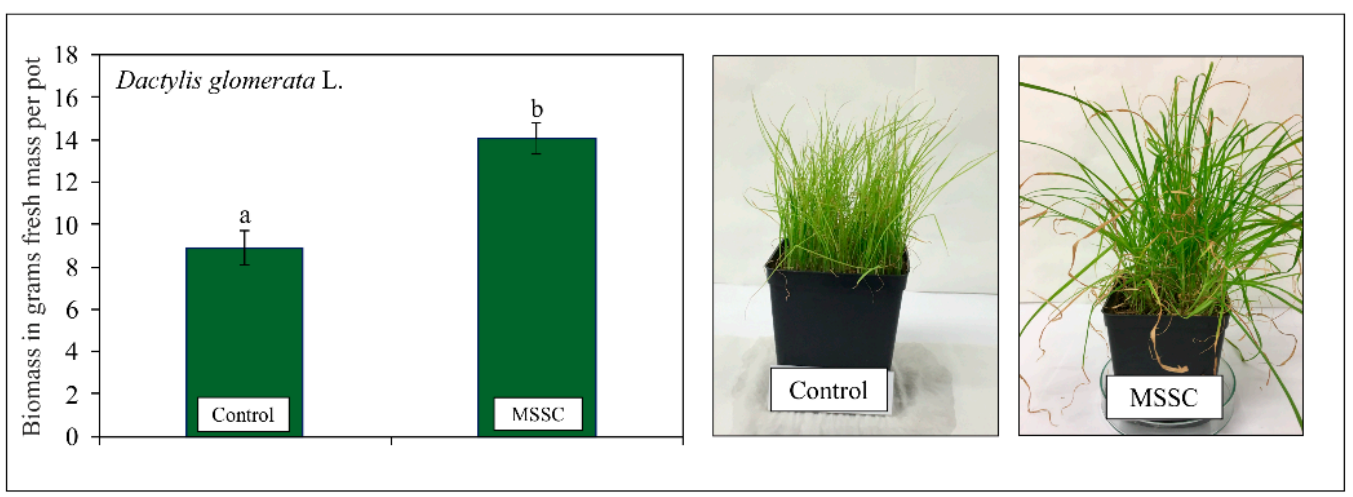

Figure 1. The average Dactylis glomerata L. biomass yield after the experiment ( $\mathrm{n}=3$, mean \pm standard deviation). Different letters indicate significant differences in biomass yield between control and MSSC-amended soil (ANOVA followed by Tukey's honest significant difference test, $p<0.05)$.

\subsection{HM Contents in the Roots and Above-Ground Parts of Dactylis glomerata L.}

The above-ground parts as well as the roots of plants can take up HM ions found in the soil in various amounts [35]. However, elevated HM contents in the soil may pose a hazard and have a phytotoxic effect on them [36]. The introduction of appropriate plant species during the implementation of the aided phytostabilization technique on soils contaminated with HMs is effective, because the roots are able to penetrate through extensive areas of the rhizosphere and take up HM ions actively and selectively [37]. The additional introduction of soil amendments that support processes in aided phytostabilization in the form of composts, for example, result in organic matter forming simple or complex chelate compounds with HMs [38]. These prevent the migration of trace elements by immobilizing them in the soil. The amounts of $\mathrm{Cu}, \mathrm{Ni}, \mathrm{Cd}, \mathrm{Pb}, \mathrm{Zn}$ and $\mathrm{Cr}$ taken up by Dactylis glomerata $\mathrm{L}$. were significantly greater in the roots than in the above-ground parts (Figure 2), with this relationship being the determinant of the correct way to proceed with processes in the aided phytostabilization technique [39]. MSSC used in the experiment was intended to form insoluble HM complexes with limited bioavailability to plants. For all the analyzed HMs, their amount in the above-ground parts was significantly smaller following the application of MSSC into the soil, with this relationship being most pronounced for metals such as $\mathrm{Cu}, \mathrm{Cd}, \mathrm{Pb}, \mathrm{Zn}$ and $\mathrm{Cr}$. Plants may exhibit a considerable tolerance to elevated $\mathrm{Cu}$ contents in soils, yet those inhabiting contaminated soils may contain this element in significant amounts within their tissues [40]. In plants, $\mathrm{Cu}$ binds with proteins and is either deposited in the intercellular spaces or retained in the roots [41]. As for Cd, whose content in the roots was two times higher in both the control series and in the pots with MSSC added, it can be related to the fact that both the root system and the above-ground parts of plants readily take it up from the soil. The resistance of plants to phytotoxic effects of $\mathrm{Cd}$ is based on the formation of the so-called phytochelates, i.e., protein compounds of various 
types which bind this element and thus, reduce its phytotoxicity [42]. Many plant species have developed a mechanism of tolerance to high Pb levels in the soil, e.g., by changing the properties of the cell membrane which increases the sorption capacity towards $\mathrm{Pb}$ through the secretion of pectin [43]. Plant roots take up $\mathrm{Pb}$ in proportion to its concentration in the soil, which was observed in the conducted study. The roots of Dactylis glomerata L. in the series with MSSC added contained an almost two times higher concentration of this element in relation to the control series. $\mathrm{Cr}$ is not an essential element for proper plant growth and development, and plants take it up passively [44]. The greatest amounts of this element accumulate in the root [45], and this relationship was confirmed in the study. In the control series and in pots with MSSC, its content was over two times higher in the roots of Dactylis glomerata $\mathrm{L}$.

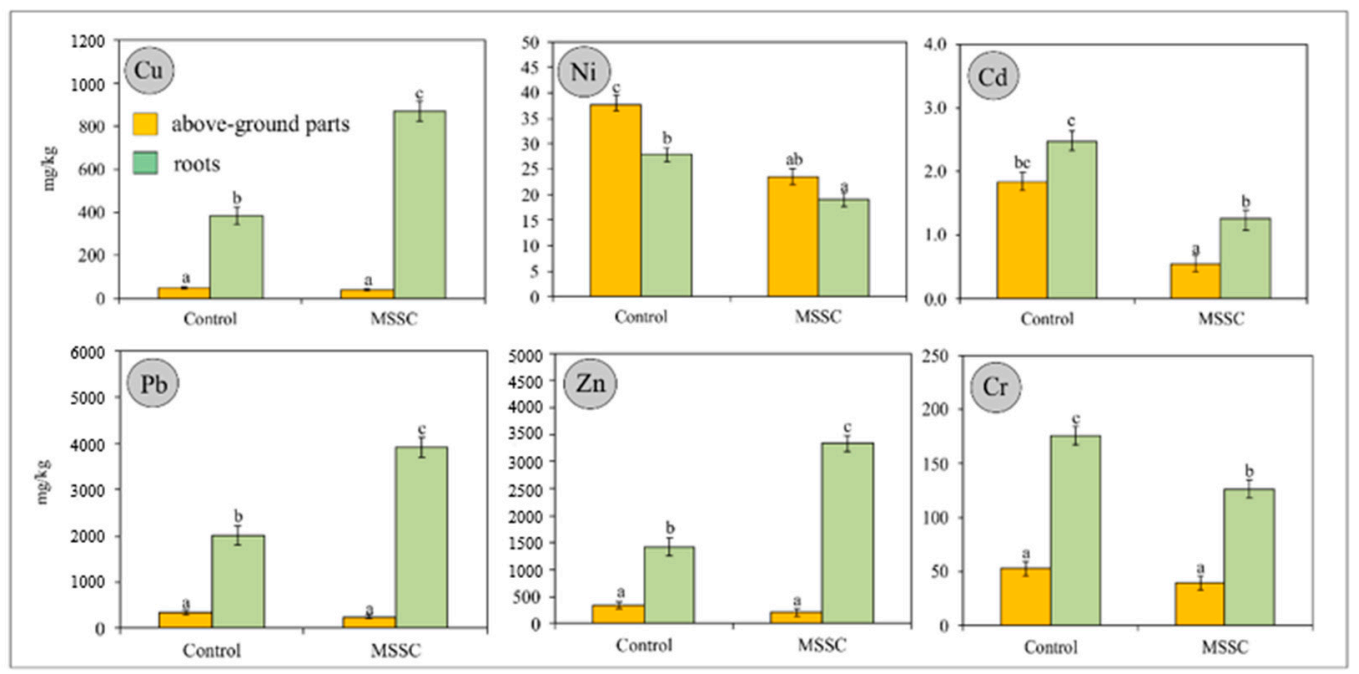

Figure 2. Contents of $\mathrm{Cu}, \mathrm{Ni}, \mathrm{Cd}, \mathrm{Pb}, \mathrm{Zn}$, and $\mathrm{Cr}$ in the above-ground parts and the roots of Dactylis glomerata $\mathrm{L}$. (n $=3$, mean \pm standard deviation). For a given HM, different letters indicate significant differences in its accumulation in above-ground parts or in the roots of Dactylis glomerata L.

\subsection{Chemical Characteristics of MSSC-Amended Soil}

A crucial soil parameter is $\mathrm{pH}$, since it significantly affects the mobility and bioavailability of HMs [46]. The acid $\mathrm{pH}$ of soils may pose a hazard to the soil-water environment, which is related to the increase in HM mobility, and thus the increase in their proportion within the biogeochemical cycle [47]. The compounds contained in composts (i.e., humic substances, mineral ions and microorganisms) may increase the immobilization of HMs in soils, thus reducing the ecological and environmental hazards associated with these contaminants [48]. The application of MSSC on soils contaminated with HMs has many advantages. First of all, the high organic matter content in compost increases the organic matter content in soils, contributing to changes in the basic physico-chemical properties of the soil $[49,50]$. An important aspect of these changes is inter alia an increase in the $\mathrm{pH}$ value, and thus a reduction in the susceptibility of individual HMs to migrations. The application of MSSC significantly contributed to an increase in the $\mathrm{pH}$ (by 1.92 units) of the soil, as compared to the soil in which this additive was not applied (Figure 3). This trend was also confirmed in other studies [4], where the addition of SSC to soils contaminated with above-standard levels of HMs also contributed to a significant increase in the $\mathrm{pH}$ value of the soil. The application of composts on soils contaminated with HMs may, despite their high $\mathrm{pH}$ value, lead to their increased transfer into the soil solution, which results in their migration within the profile and an increase in the plant uptake [44]. The contents of $\mathrm{Cu}, \mathrm{Ni}$, $\mathrm{Cd}, \mathrm{Pb}, \mathrm{Zn}$ and $\mathrm{Cr}$ in the soil before and after the experiment varied and were determined by the type of HMs (Figure 4). For each of the analyzed HM, a significant reduction in the content in the soil was observed following the completion of the phytostabilization process. 
This effect was particularly pronounced for $\mathrm{Ni}, \mathrm{Zn}$, and $\mathrm{Cr}$ following the application of MSSC, where the HM concentration was lower by $62 \%, 70 \%$, and $56 \%$, respectively.

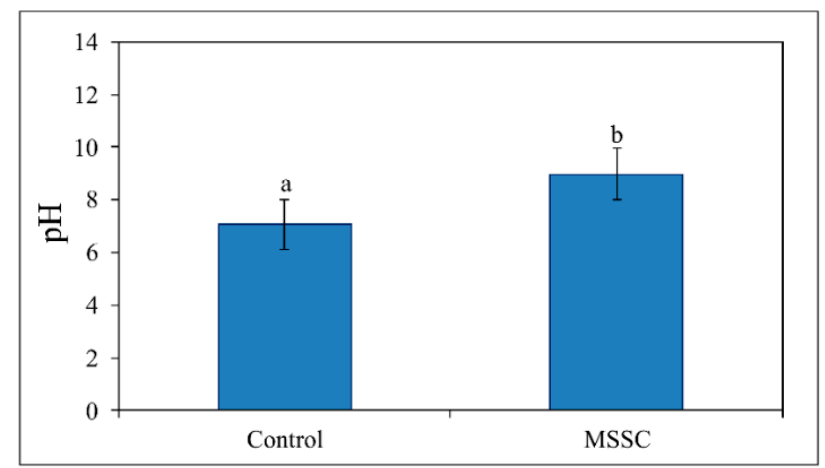

Figure 3. The $\mathrm{pH}$ value of the soil after the experiment. Different letters indicate significant differences in $\mathrm{pH}$ value of soil control soil and MSSC-amended soil.

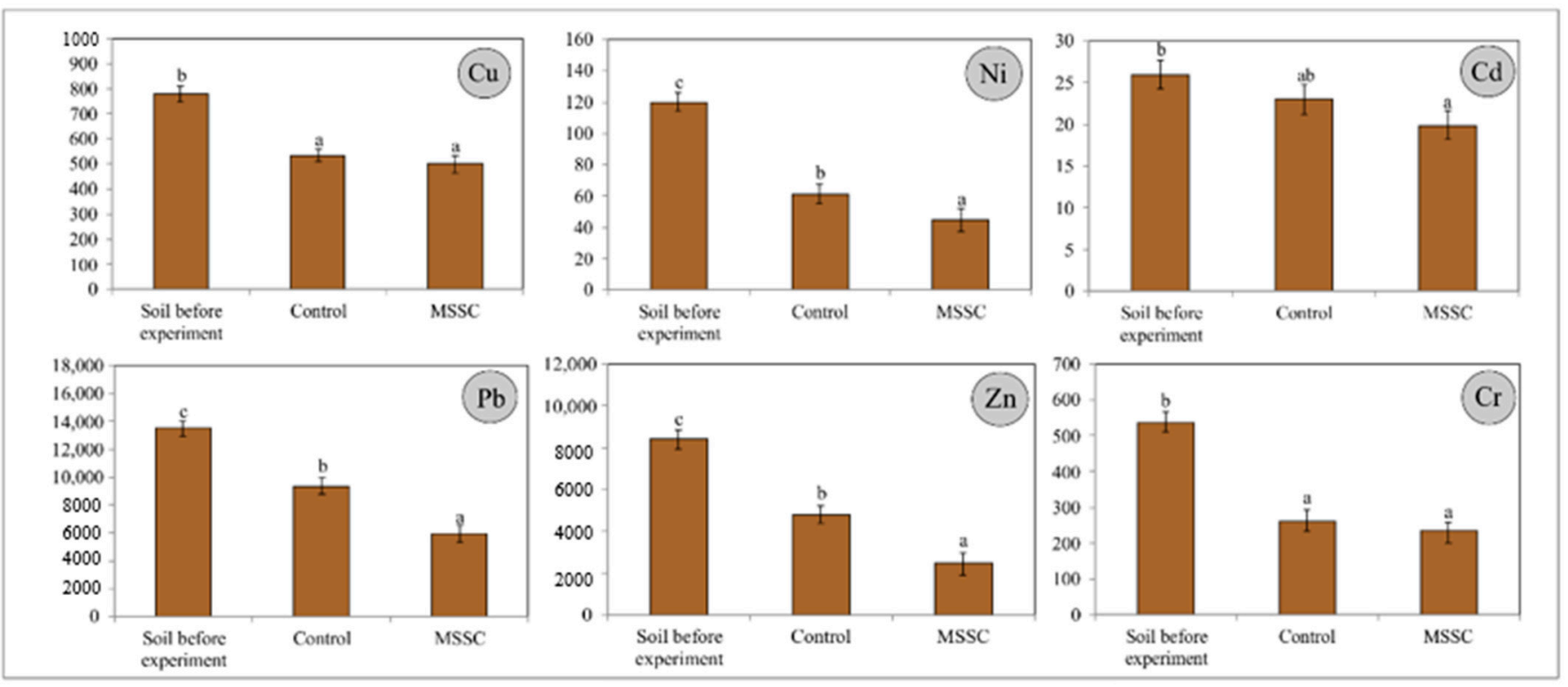

Figure 4. Contents of $\mathrm{Cu}, \mathrm{Ni}, \mathrm{Cd}, \mathrm{Pb}, \mathrm{Zn}$, and $\mathrm{Cr}$ in the soil after the experiment ( $\mathrm{n}=3$, mean \pm standard deviation). For a given $\mathrm{HM}$, different letters indicate significant differences in HM content in soil before experiment, control soil and MSSC-amended soil.

\section{Conclusions}

The occurrence of significant amounts of HMs in the soil can disturb the natural balance and increase the risk of incorporating metals into the trophic chain. It is therefore important to develop environmentally friendly methods aimed at minimizing the risk of HM occurrence in soils, e.g., through aided phytostabilization. On the other hand, the application of MSS compost in soil environment remediation techniques allows nutrient cycling to be maintained, and results in the termination of element cycling in the ecosystem. The study results obtained indicate that MSSC can be applied in supporting HM immobilization processes, and can ensure adequate biomass increase in the aided phytostabilization technique. Ultimately, the following were demonstrated after the experiment: a significantly greater accumulation of $\mathrm{Cu}, \mathrm{Ni}, \mathrm{Cd}, \mathrm{Pb}, \mathrm{Zn}$ and $\mathrm{Cr}$ in the roots of Dactylis glomerata L., a greater yield of the above-ground biomass and a higher $\mathrm{pH}$ of the soil as well as reduced contents of $\mathrm{Ni}, \mathrm{Zn}$, and $\mathrm{Cr}$ in the soil, with an addition of MSSC. 
Author Contributions: Conceptualization, M.R. and Z.M.G.; methodology, M.R.; software, A.B.; validation, T.H., E.K. and W.S.; formal analysis, J.H.; investigation, M.R.; resources, J.C. and Ł.S.; data curation, B.K.K.; writing-original draft preparation, M.R. and Z.M.G.; writing-review and editing, M.B.; visualization, E.L.; supervision, M.B.; funding acquisition, Z.M. All authors have read and agreed to the published version of the manuscript.

Funding: This research was funded by a project financially supported by the Ministry of Science and Higher Education in the auspices of the program entitled "Regional Initiative of Excellence" for the years 2019-2022, Project No. 010/RID/2018/19 (amount of funding 12,000,000 PLN).

Institutional Review Board Statement: Not applicable.

Data Availability Statement: Not applicable.

Conflicts of Interest: The authors declare no conflict of interest.

\section{References}

1. Lin, W.Y.; Ng, W.C.; Wong, B.S.E.; Teo, S.L.M.; Sivananthan, G.; Baeg, G.H.; Ok, Y.S.; Wang, C.H. Evaluation of sewage sludge incineration ash as a potential land reclamation material. J. Hazard. Mater. 2018, 357, 63-72. [CrossRef] [PubMed]

2. Zhang, Q.; Zou, D.; Zeng, X.; Li, L.; Wang, A.; Liu, F.; Wang, H.; Zeng, Q.; Xiao, Z. Effect of the direct use of biomass in agricultural soil on heavy metals activation or immobilization? Environ. Pollut. 2021, 272, 115989. [CrossRef] [PubMed]

3. Ma, P.; Rosen, C. Land application of sewage sludge incinerator ash for phosphorus recovery: A review. Chemosphere 2021, 274, 129609. [CrossRef]

4. Zhou, G.; Gu, Y.; Yuan, H.; Gong, Y.; Wu, Y. Selecting sustainable technologies for disposal of municipal sewage sludge using a multi-criterion decision-making method: A case study from China. Resour. Conserv. Recycl. 2020, 161, 104881. [CrossRef]

5. Environment; Statistics Poland: Warsaw, Poland, 2020. (In Polish)

6. Rékási, M.; Mazsu, N.; Draskovits, E.; Bernhardt, B.; Szabó, A.; Rivier, P.A.; Farkas, C.; Borsányi, B.; Pirkó, B.; Molnár, S.; et al. Comparing the agrochemical properties of compost and vermicomposts produced from municipal sewage sludge digestate. Bioresour. Technol. 2019, 291, 121861. [CrossRef]

7. Rehman, R.A.; Qayyum, M.F. Co-composts of sewage sludge, farm manure and rock phosphate can substitute phosphorus fertilizers in rice-wheat cropping system. J. Enviorn. Manag. 2020, 259, 109700. [CrossRef] [PubMed]

8. Vitti, A.; Elshafie, H.S.; Logozzo, G.; Marzario, S.; Scopa, A.; Camele, I.; Nuzzaci, M. Physico-chemical Characterization and Biological Activities of A Digestate and A More Stabilized Digestate-Derived Compost from Agro-Waste. Plants 2021, 10, 386. [CrossRef]

9. Radziemska, M.; Gusiatin, Z.M.; Cydzik-Kwiatkowska, A.; Cerdà, A.; Pecina, V.; Bęś, A.; Datta, R.; Majewski, G.; Mazur, Z.; Dzięcioł, J.; et al. Insight into metal immobilization and microbial community structure in soil from a steel disposal dump that was phytostabilized with composted, pyrolyzed or gasified wastes. Chemosphere 2021, 272, 129576. [CrossRef]

10. Visconti, D.; Álvarez-Robles, M.J.; Fiorentino, N.; Fagnano, M.; Clemente, R. Use of Brassica juncea and Dactylis glomerata for the phytostabilization of mine soils amended with compost or biochar. Chemosphere 2020, 260, 127661. [CrossRef]

11. Ke, T.; Guo, G.; Liu, J.; Zhang, C.; Tao, Y.; Wang, P.; Xu, Y.; Chen, L. Improvement of the Cu and Cd phytostabilization efficiency of perennial ryegrass through the inoculation of three metal-resistant PGPR strains. Environ. Pollut. 2021, 271, 116314. [CrossRef]

12. Bomfim, N.C.P.; Aguilar, J.V.; de Paiva, W.S.; de Souza, L.A.; Justino, G.C.; Faria, A.A.; Camargos, L.S. Iron phytostabilization by Leucaena leucocephala. S. Afr. J. Bot. 2021, 138, 318-327. [CrossRef]

13. Radziemska, M.; Mazur, Z.; Jeznach, J. Influence of applying halloysite and zeolite to soil contaminated with nickel on the content of selected elements in Maize (Zea mays L.). Chem. Eng. Trans. 2013, 32, 301-306.

14. Wyszkowski, M.; Radziemska, M. Influence of chromium (III) and (VI) on the concentration of mineral elements in oat (Avena sativa L.). Fresenius Environ. Bull. 2013, 22, 979-986.

15. Bai, T.; Liu, Y.Y.; Muhammad, I.; Yang, X.; Yin, X.J.; Bai, L.; Wang, Y.J. Mixed nitrogen form addition facilitates the growth adaptation of legume plant to heavy metal contamination in degraded mining areas. Glob. Ecol. Conserv. 2020, 24 , e01387. [CrossRef]

16. Xue, K.; Zhou, J.; Van Nostrand, J.; Mench, M.; Bes, C.; Giagnoni, L.; Renella, G. Functional activity and functional gene diversity of a Cu-contaminated soil remediated by aided phytostabilization using compost, dolomitic limestone and a mixed tree stand. Environ. Pollut. 2018, 242, 229-238. [CrossRef]

17. Kowitwiwat, A.; Sampanpanish, P. Phytostabilization of arsenic and manganese in mine tailings using Pennisetum purpureum cv. Mott supplemented with cow manure and acacia wood-derived biochar. Heliyon 2020, 6, e04552. [CrossRef] [PubMed]

18. Pogrzeba, M.; Rusinowski, S.; Krzyżak, J.; Szada-Borzyszkowska, A.; McCalmont, J.P.; Zieleźnik-Rusinowska, P.; Słaboń, N.; Sas-Nowosielska, A. Dactylis glomerata L. cultivation on mercury contaminated soil and its physiological response to granular sulphur aided phytostabilization. Environ. Pollut. 2019, 255, 113271. [CrossRef]

19. Kulikowska, D.; Klimiuk, E. Organic Matter Transformations and Kinetics during Sewage Sludge Composting in a Two-Stage System. Bioresour. Technol. 2011, 102, 10951-10958. [CrossRef] 
20. Sulieman, M.; Saeed, I.; Hassaballa, A.; Rodrigo-Comino, J. Modeling cation exchange capacity in multi geochronological-derived alluvium soils: An approach based on soil depth intervals. Catena 2018, 167, 327-339. [CrossRef]

21. Enya, O.; Heaney, N.; Iniama, G.; Lin, C. Effects of heavy metals on organic matter decomposition in inundated soils: Microcosm experiment and field examination. Sci. Total Environ. 2020, 724, 138223. [CrossRef]

22. Shrestha, P.; Bellitürk, K.; Görres, J.H. Phytoremediation of heavy metal-contaminated soil by switchgrass: A comparative study utilizing different composts and coir fiber on pollution remediation, plant productivity, and nutrient leaching. Int. J. Environ. Res. Public Health 2019, 16, 1261. [CrossRef]

23. Guo, D.; Fan, Z.; Lu, S.; Ma, Y.; Nie, X.; Tong, F.; Peng, X. Changes in rhizosphere bacterial communities during remediation of heavy metal-accumulating plants around the Xikuangshan mine in southern China. Sci. Rep. 2019, 9, 1-11. [CrossRef] [PubMed]

24. Diaconu, M.; Pavel, L.V.; Hlihor, R.M.; Rosca, M.; Fertu, D.I.; Lenz, M.; Corvini, P.X.; Gavrilescu, M. Characterization of heavy metal toxicity in some plants and microorganisms-A preliminary approach for environmental bioremediation. New Biotechnol. 2020, 56, 130-139. [CrossRef]

25. Shah, V.; Daverey, A. Effects of sophorolipids augmentation on the plant growth and phytoremediation of heavy metal contaminated soil. J. Clean. Prod. 2021, 280, 124406. [CrossRef]

26. Wei, L.; Zhang, J.; Wang, C.; Liao, W. Recent progress in the knowledge on the alleviating effect of nitric oxide on heavy metal stress in plants. Plant Physiol. Biochem. 2020, 147, 161-171. [CrossRef] [PubMed]

27. Tripathi, S.; Sharma, P.; Singh, K.; Purchase, D.; Chandra, R. Translocation of heavy metals in medicinally important herbal plants growing on complex organometallic sludge of sugarcane molasses-based distillery waste. Environ. Technol. Innov. 2021, $22,101434$. [CrossRef]

28. Antonkiewicz, J.; Popławska, A.; Kołodziej, B.; Ciarkowska, K.; Gambuś, F.; Bryk, M.; Babula, J. Application of ash and municipal sewage sludge as macronutrient sources in sustainable plant biomass production. J. Environ. Manag. 2020, 264, 110450. [CrossRef]

29. Kirchmann, H.; Borjesson, G.; Katterer, T.; Cohen, Y. From agricultural use of sewage sludge to nutrient extraction: A soil science outlook. Ambio 2017, 46, 143-154. [CrossRef]

30. Kumi, S.; Addo-Fordjour, P.; Fei-Baffoe, B.; Belford, E.J.D. Yaw Ameyaw, Land use land cover dynamics and fragmentationinduced changes in woody plant community structure in a mining landscape, Ghana. Trees People 2021, 4, 100070. [CrossRef]

31. Radziemska, M.; Vaverková, M.D.; Mazur, Z. Pilot scale use of compost combined with sorbents to phytostabilize Ni-contaminated soil using Lolium perenne L. Wast Biomass Valor. 2019, 10, 1585-1595. [CrossRef]

32. Zhang, L.; Sun, X.; Tian, Y.; Gong, X. Biochar and humic acid amendments improve the quality of composted green waste as a growth medium for the ornamental plant Calathea insignis. Sci. Hortic. 2014, 176, 70-78. [CrossRef]

33. Awasthi, M.K.; Wang, Q.; Awasthi, S.K.; Li, R.; Zhao, J.; Ren, X.; Wang, M.; Chen, H.; Zhang, Z. Feasibility of medical stone amendment for sewage sludge co-composting and production of nutrient-rich compost. J. Environ. Manag. 2018, $216,49-61$. [CrossRef]

34. Cárdenas-Aguiar, E.; Gascó, G.; Paz-Ferreiro, J.; Méndez, A. The effect of biochar and compost from urban organic waste on plant biomass and properties of an artificially copper polluted soil. Int. Biodeterior. Biodegrad. 2017, 124, 223-232. [CrossRef]

35. Feng, R.W.; Wang, L.Z.; Yang, J.G.; Zhao, P.P.; Zhu, Y.M.; Li, Y.P.; Yu, Y.S.; Liu, H.; Rensing, C.; Wu, Z.Y.; et al. Underlying mechanisms responsible for restriction of uptake and translocation of heavy metals (metalloids) by selenium via root application in plants. J. Hazard. Mater. 2021, 402, 123570. [CrossRef] [PubMed]

36. Mohamed, B.A.; Ellis, N.; Kim, C.S.; Bi, X.; Chen, W.H. Engineered biochars from catalytic microwave pyrolysis for reducing heavy metals phytotoxicity and increasing plant growth. Chemosphere 2021, 271, 129808. [CrossRef]

37. Sajad, M.A.; Khan, M.S.; Bahadur, S.; Naeem, A.; Ali, H.; Batool, F.; Shuaib, M.; Anwar, M.; Khan, S.; Batool, S. Evaluation of chromium phytoremediation potential of some plant species of Dir Lower, Khyber Pakhtunkhwa, Pakistan. Acta Ecol. Sin. 2020, 40, 158-165. [CrossRef]

38. Gil-Loaiza, J.; White, S.A.; Root, R.A.; Solís-Dominguez, F.A.; Hammond, C.M.; Chorover, J.; Maier, R.M. Phytostabilization of mine tailings using compost-assisted direct planting: Translating greenhouse results to the field. Sci. Total Environ. 2016, 565, 451-461. [CrossRef] [PubMed]

39. Garau, M.; Castaldi, P.; Diquattro, S.; Pinna, M.V.; Senette, C.; Roggero, P.P.; Garau, G. Combining grass and legume species with compost for assisted phytostabilization of contaminated soils. Environ. Technol. Innov. 2021, 22, 101387. [CrossRef]

40. Kumar, V.; Pandita, S.; Sidhu, G.P.S.; Sharma, A.; Khanna, K.; Kaur, P.; Bali, A.S.; Setia, R. Copper bioavailability, uptake, toxicity and tolerance in plants: A comprehensive review. Chemosphere 2021, 262, 127810. [CrossRef]

41. Shabbir, Z.; Sardar, A.; Shabbir, A.; Abbas, G.; Shamshad, S.; Khalid, S.; Murtaza, N.G.; Dumat, C.; Shahid, M. Copper uptake, essentiality, toxicity, detoxification and risk assessment in soil-plant environment. Chemosphere 2020, 259, 127436. [CrossRef]

42. Qin, S.; Liu, H.; Nie, Z.; Rengel, Z.; Gao, W.; Li, C.; Zhao, P. Toxicity of cadmium and its competition with mineral nutrients for uptake by plants: A review. Pedosphere 2020, 30, 168-180. [CrossRef]

43. García-Sánchez, M.; Silva-Castro, G.A.; Sanchez, A.; Arriagada, C.; García-Romera, I. Effect of arbuscular mycorrhizal fungi and mycoremediated dry olive residue in lead uptake in wheat plants. Appl. Soil Ecol. 2021, 159, 103838. [CrossRef]

44. Laurent, C.; Bravin, M.N.; Crouzet, O.; Pelosi, C.; Tillard, E.; Lecomte, P.; Lamy, I. Increased soil pH and dissolved organic matter after a decade of organic fertilizer application mitigates copper and zinc availability despite contamination. Sci. Total Environ. 2020, 709, 135927. [CrossRef] [PubMed] 
45. Zhao, Y.; Hu, C.; Wang, X.; Qing, X.; Wang, P.; Zhang, Y.; Zhang, H.; Zhao, X. Selenium alleviated chromium stress in Chinese cabbage (Brassica campestris L. ssp. Pekinensis) by regulating root morphology and metal element uptake. Ecotoxicol. Environ. Saf. 2019, 173, 314-321. [CrossRef] [PubMed]

46. Kim, K.; Yoon, S.; Kwon, H.A.; Choi, Y. Effects of treatment agents during acid washing and pH neutralization on the fertility of heavy metal-impacted dredged marine sediment as plant-growing soil. Environ. Pollut. 2020, 267, 115466. [CrossRef] [PubMed]

47. Martínez-Cortijo, J.; Ruiz-Canales, A. Effect of heavy metals on rice irrigated fields with waste water in high $\mathrm{pH}$ Mediterranean soils: The particular case of the Valencia area in Spain. Agric. Water Manag. 2018, 210, 108-123. [CrossRef]

48. Shaheen, S.M.; Niazi, N.K.; Hassan, N.E.; Bibi, I.; Wang, H.; Tsang, D.C.; Ok, Y.S.; Bolan, N.; Rinklebe, J. Wood-based biochar for the removal of potentially toxic elements in water and wastewater: A critical review. Int. Mater. Rev. 2019, 64, 216-247. [CrossRef]

49. Chen, K.; Fijen, T.P.M.; Kleijn, D.; Scheper, J. Insect pollination and soil organic matter improve raspberry production independently of the effects of fertilizers. Agric. Ecosyst. Environ. 2021, 309, 107270. [CrossRef]

50. Wang, H.; Xu, J.; Liu, X.; Zhang, D.; Li, L.; Li, W.; Sheng, L. Effects of long-term application of organic fertilizer on improving organic matter content and retarding acidity in red soil from China. Soil Tillage Res. 2019, 195, 104382. [CrossRef] 